\title{
Correction to: Proteomic landscape of Alzheimer's Disease: novel insights into pathogenesis and biomarker discovery
}

Bing Bai ${ }^{1,3^{*+}}$, David Vanderwall ${ }^{1 \dagger}$, Yuxin $\mathrm{Li}^{1,2}$, Xusheng Wang ${ }^{2,4}$, Suresh Poudel ${ }^{1,2}$, Hong Wang $^{1,2}$, Kaushik Kumar Dey ${ }^{1}$, Ping-Chung Chen ${ }^{1}, \mathrm{Ka} \mathrm{Yang}^{1}$ and Junmin Peng ${ }^{1,2^{*}}$

Correction to: Mol Neurodegener 16, 55 (2021) https://doi.org/10.1186/s13024-021-00474-z

The original article [1] contained an error in Corresponding Authorship designation.

This has since been corrected.

\begin{abstract}
Author details
${ }^{1}$ Departments of Structural Biology and Developmental Neurobiology, St. Jude Children's Research Hospital, Memphis, TN 38105, USA. ${ }^{2}$ Center for Proteomics and Metabolomics, St. Jude Children's Research Hospital, Memphis, TN 38105, USA. ${ }^{3}$ Current address: Center for Precision Medicine, Department of Laboratory Medicine, Nanjing Drum Tower Hospital, The Affiliated Hospital of Nanjing University Medical School, Nanjing 210008, Jiangsu, China. ${ }^{4}$ Current address: Department of Biology, University of North Dakota, Grand Forks, ND 58202, USA.
\end{abstract}

Published online: 20 October 2021

\section{Reference}

1. Bai B, Vanderwall D, Li Y, Wang X, Poudel S, Wang H, et al. Proteomic landscape of Alzheimer's Disease: novel insights into pathogenesis and biomarker discovery. Mol Neurodegener. 2021;16(1):55. https://doi.org/10.11 86/s13024-021-00474-z.

\footnotetext{
The original article can be found online at https://doi.org/10.1186/s13024021-00474-z

* Correspondence: Bing.Bai@nju.edu.cn; Junmin.Peng@STJUDE.ORG

${ }^{\dagger}$ Bing Bai and David Vanderwall contributed equally to this work.

'Departments of Structural Biology and Developmental Neurobiology, St. Jude Children's Research Hospital, Memphis, TN 38105, USA

Full list of author information is available at the end of the article
}

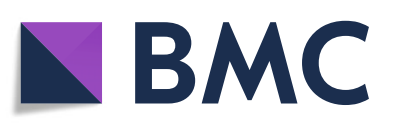

() The Author(s). 2021 Open Access This article is licensed under a Creative Commons Attribution 4.0 International License, which permits use, sharing, adaptation, distribution and reproduction in any medium or format, as long as you give appropriate credit to the original author(s) and the source, provide a link to the Creative Commons licence, and indicate if changes were made. The images or other third party material in this article are included in the article's Creative Commons licence, unless indicated otherwise in a credit line to the material. If material is not included in the article's Creative Commons licence and your intended use is not permitted by statutory regulation or exceeds the permitted use, you will need to obtain permission directly from the copyright holder. To view a copy of this licence, visit http://creativecommons.org/licenses/by/4.0/. The Creative Commons Public Domain Dedication waiver (http://creativecommons.org/publicdomain/zero/1.0/) applies to the data made available in this article, unless otherwise stated in a credit line to the data. 